\title{
Novel hydroxyamides and amides containing D-glucopyranose or D-fructose units: Biological assays in MCF-7 and MDST8 cell lines
}

\author{
Elisabete P. Carreiro ${ }^{\mathrm{a}, *}$, Ana R. Costa ${ }^{\mathrm{b}, \mathrm{c}}$, Maria M. Cordeiro ${ }^{\mathrm{b}}$, Rute Martins ${ }^{\mathrm{b}}$, Tiago O. Pires ${ }^{\mathrm{b}}$, \\ Mafalda Saraiva $^{\mathrm{b}}$, Célia M. Antunes ${ }^{\mathrm{b}, \mathrm{c}, \mathrm{d}}$, Anthony J. Burke ${ }^{\mathrm{a}, \mathrm{b}}$ \\ ${ }^{a}$ Centro de Química de Évora, IIFA, Universidade de Évora, Colégio L.A. Verney, 7000 Évora, Portugal \\ ${ }^{\mathrm{b}}$ Departamento de Química, Universidade de Évora, Rua Romão Ramalho, 59, 7000 Évora, Portugal \\ ' Instituto de Ciências Agrarias e Ambientais Mediterrânicas (ICAAM), Apartado 94, 7002-554 Universidade de Évora, Portugal \\ ${ }^{\mathrm{d}}$ Center For Neurosciences and Cell Biology, University of Coimbra, Portugal
}

\section{A R T I C L E I N F O}

\section{Article history:}

Received 21 October 2015

Revised 6 December 2015

Accepted 10 December 2015

Available online 12 December 2015

\section{Keywords:}

Hydroxyamides

D-Glucuronic acid

Anti-tumor

MCF-7

MDST8

\begin{abstract}
A B S T R A C T
A novel library of 15 compounds, hydroxyamides and amides containing a $\beta$-D-glucopyranose (D-Gluc) or a $\beta$-D-fructose (D-Fruc) units was designed and synthesized for antiproliferative assays in breast (MCF-7) and colon (MDST8) cancer cell lines. Twelve of them were hydroxyamides and were successfully synthesized from $\beta$-D-glucuronic acid (D-GluA). Six of these hydroxyamides which were acetylated hydroxy- $\beta$-Dglucopyranuronamide 2a-2f (1st Family) and the other six were their respective isomers, that is, hydroxy- $\beta$-D-fructuronamide 3a-3f (2nd Family), obtained by acid-base catalyzed isomerization. These compounds have the general structure, $\mathrm{D}-\mathrm{Gluc}-\mathrm{C}=\mathrm{ONH}-\mathrm{CHR}-\left(\mathrm{CH}_{2}\right)_{n}-\mathrm{OH}$ and $\mathrm{D}-\mathrm{Fruc}-\mathrm{C}=\mathrm{ONH}-\mathrm{CHR}-$ $\left(\mathrm{CH}_{2}\right)_{n}-\mathrm{OH}$, where $\mathrm{R}=$ an aromatic, alkyl or a hydrogen substituent, with $n=0$ or 1 . Eight of these contained a chiral aminoalcohol group. Three compounds were amides containing a D-glucopyranose unit (3rd Family). SAR studies were conducted with these compounds. Antiproliferative studies showed that compound 4a, the bromo-amide containing the $\beta$-D-glucopyranose ring, potently inhibits the proliferation of the MDST8 cells. Five compounds ( $2 \mathbf{e}, \mathbf{2} \mathbf{f}, \mathbf{3 d}, \mathbf{3 e}$, and $\mathbf{3 f}$ ) were shown to potently selectively inhibit the proliferation of the MCF-7 cells. Compound $\mathbf{4 b}$ was the only one showing inhibition in both cell lines. In general, the more active compounds were the amides and hydroxyamides containing the $\beta$-D-fructose moiety, and containing an alkyl group or hydrogen. Half-inhibitory concentrations $\left(\mathrm{IC}_{50}\right)$ of between 0.01 and $10 \mu \mathrm{M}$, were observed.
\end{abstract}

(c) 2015 Elsevier Ltd. All rights reserved.
Cancer is currently one of the most lethal diseases in the world. Chemotherapy is the most common treatment used for this disease, which is usually integrated with surgery and radiation therapy. For this reason cancer drug discovery is extremely important. Carbohydrates are one of the most abundant biomolecules on our planet, and currently carbohydrate scaffolds are being developed for new drugs, as they are intricately involved in interand intracellular communication processes. ${ }^{1}$ Synthetic and natural compounds containing the D-glucuronic acid unit have wide ranging pharmacological activities, that include antibiotic, antiviral, antibacterial and antitumoral activity. Gougerotin, Bagougeramine $\mathrm{A}$ and $\mathrm{B}$ are some examples ${ }^{2}$ of biologically active compounds containing a 4-amido-glucuronamide motif. $\beta$-Glucuronides are used like prodrugs for selective cancer chemotherapy, the active drug is released by the action of endogenous intracellular

\footnotetext{
* Corresponding author. Tel.: +351 266745312; fax: +351266702306.

E-mail address: bete_carreiro@yahoo.com (E.P. Carreiro).
}

$\beta$-glucuronidase enzymes (they show elevated concentrations in tumors compared to normal tissues), and this reduces the toxicity of the chemotherapy process. ${ }^{3}$ Recently, El-Nezhawy et al. ${ }^{4}$ synthesized and evaluated antitumoral activity of some novel acetylated and deacetylated D-glucuronic acid derivatives and screened them for antitumor activity using MCF-7, TK-10 and UACC-62 cell lines. Although a molecular target was not indicated, these studies revealed some promising compounds for human breast adenocarcinoma (MCF-7) growth inhibition such as $N$-(pyridine-4-yl)1,2,3,4-tetra- $O$-acetyl- $\beta$-D-glucopyranuronamide (A) and allyl 1,2,3,4-tetra-O-acetyl- $\beta$-D-glucopyranuronate (B) (Fig. 1). Hydroxamic acid derivatives play a very important role in cancer therapy, they are known to be inhibitors of histone deacetylases (HDACs). ${ }^{5}$ For example, suberanilohydroxamic acid - SAHA (vorinostat) (Fig. 1 ) is one of most clinically advanced HDAC inhibitors. ${ }^{6}$ A large number of preclinical studies demonstrate that SAHA can induce growth arrest, differentiation and apoptosis in a wide range of cancer cell lines by re-expression of genes (i.e., thioredoxin-binding 


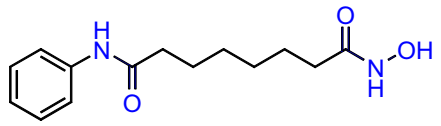

Vorinostat (SAHA) - MCF-7 IC ${ }_{50}=2.5 \mu \mathrm{M}$
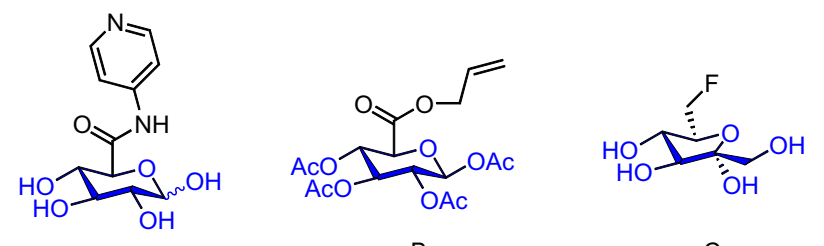

A

MCF-7 IC ${ }_{50}=0.19 \mu \mathrm{M}$

C

Selective Uptake

Figure 1. Some compounds with anticancer activity.

protein-2). ${ }^{7}$ SAHA contains a hydroxamic acid group (R-CO-NH$\mathrm{OH}$ ), which coordinates with $\mathrm{Zn}$ and can also form hydrogen bonds with the amino acids residues of the HDAC active site, containing the triad; Tyr306, His142, His143. ${ }^{8}$ The $\mathrm{IC}_{50}$ value obtained for SAHA against MCF-7 was $2.5 \mu \mathrm{M}^{9}$

Fructose derivatives also have an important biological application, such as for fructose transporter GLUT5 ${ }^{10}$ inhibition and anticonvulsant activity. Fluorescent fructose derivatives were used as diagnostic reagents for breast cancer. ${ }^{11}$ Based on recent research, the overexpression of GLUT5 is an intrinsic characteristic of some breast cancer cell lines, but not for normal tissue. ${ }^{12}$ This selective expression could represent a potential therapeutic target. A few examples of the successful application of this concept, employing selective uptake of fructose analogues 6-deoxy-6-fluoro-D-fructose (C) (Fig. 1) $)^{11 \mathrm{a}}$ and their phosphorescent metal complexes have appeared in the literature. ${ }^{13}$ Most workers in this field synthesize these fructose analogues by isomerization of glucose. Various methods have been described, such as with enzymes, ${ }^{14}$ Lewis acids, ${ }^{15}$ zeolites ${ }^{16}$ and ion-exchange resins. ${ }^{17}$

Our goal was to synthesize three novel families, two of which consisted of hydroxyamide derivatives of D-glucuronic acid, 1st Family (compounds 2a-2f) and the 2nd Family (compounds 3a3f). The 3rd Family (compounds $\mathbf{4 a - 4 c}$ ) was composed of amide derivatives of $\mathrm{D}$-glucuronic acid containing a bromo or pyrrolidine ring on the amide tether (Fig. 2). We decided to introduce pyrrolidine rings into these molecules given that this unit behaves generally as an important biostere, present in many molecules active against cancer. ${ }^{18}$ Our molecules were designed based on the two biomolecular targets described above. In the case of HDAC inhibition, the hydroxyamide and amide attached to the glucopyranose unit, the $-\mathrm{OH}$ and $-\mathrm{NH}$ - were designed to function like a zincbinding group, forming a $\mathrm{H}$-bond with key $\mathrm{H}$-bonding amino acid residues in the active site. In the case of the fructose derivatives, they were designed as GLUT5 transporter inhibitors. The fructose analogues are expected to be recognized by the GLUT5 receptor and the hydroxyl groups important for $\mathrm{H}$-bonding and binding in the central cavity. ${ }^{19}$ The hydroxyl group is crucial for establishing $\mathrm{H}$-bonds in the active site of the potentials biological targets, thus improving the compounds inhibitory effect and consequently its antitumor activity. Eight of the 12 compounds in our library have a stereogenic center in the hydroxyamide side chain group. These molecules were evaluated in antiproliferative tests in the human breast adenocarcinoma (MCF-7) and colon adenocarcinoma (MDST8) cell lines. 5-Fluorouracil (5-FU), which is an antineoplasic agent, was used as a bench-mark.

The 1st and 3rd Families of compounds $2 \mathbf{a}-\mathbf{2 f}$ and $\mathbf{4 a - 4 c}$, respectively, were successfully synthesized according to the general procedure reported in Scheme 1. Compound 1, 1,2,3,

4-tetra-O-acetyl- $\beta$-D-glucopyranuronic acetic anhydride was synthesized from commercial D-glucuronic acid by treating it with $\mathrm{AcO}_{2} / \mathrm{I}_{2}$ using the method described by Tosin and Murphy. ${ }^{20}$ Using the method initially developed by El-Nezhawy et al., ${ }^{4}$ compound $\mathbf{1}$ was reacted with the hydroxyamines I.a-f or amines II.a-c furnishing the corresponding amidoalcohols $\mathbf{2 a - 2 f}$ and amides $\mathbf{4 a - 4 c}$, in very good yields, between $24 \%$ and $85 \%$. The structure of the compounds $\mathbf{2 a - 2 f}$ and $\mathbf{4 a}-\mathbf{4 c}$, was confirmed by NMR spectroscopy.

${ }^{1} \mathrm{H}$ NMR analysis confirmed the structures of all the acetylated compounds $\mathbf{2 a - 2 f}$ and $\mathbf{4 a - 4 c}$, in general for all compounds, the anomeric proton appears as a doublet around $5.70 \mathrm{ppm}(\mathrm{J}=8 \mathrm{~Hz})$ which corresponds to the diaxial orientation for both the anomeric proton and the adjacent proton $(\mathrm{H}-2)$, thus confirming the $\beta$-anomeric configuration.

${ }^{13} \mathrm{C}$ NMR was used also to characterize the acetylated compounds. These compounds were characterized by a signal at $91.2 \mathrm{ppm}$ corresponding to the anomeric carbon of the $\beta$-D-glucopyranose ring.

The second Family, was synthesized by isomerization of compounds 2a-2f, (Scheme 2) using NaOMe to deprotect the acetyl groups and at the same time opening the pyran ring to form the aldose (1st step) or the enolate. The proposed mechanism is depicted in Scheme 3. The strong acid resin $\left(\mathrm{H}^{+}\right)$, Amberlite IR120, was used for ionic exchange of the $\mathrm{Na}^{+}$with $\mathrm{H}^{+}$, further keto-enol tautomerism to form the ketone followed by cyclization onto the ketone (2nd Step) was proposed to give 3c.

NMR studies were conducted to probe the reaction mechanism. Compound 2c was dissolved in MeOD and NaOMe (5.5 equiv) and analyzed by ${ }^{1} \mathrm{H}$ NMR. After $30 \mathrm{~min}$ a strong signal at $10 \mathrm{ppm}$ appeared indicating the presence of the aldehyde or enolate (as the base could probably form the enolate under these conditions). Amberlite IR120 $\left(\mathrm{H}^{+}\right)$was then added, analysis by ${ }^{1} \mathrm{H}$ NMR showed the presence of a mixture of anomers, consisting of $80 \%$ $\beta$-D-fructose and $20 \%$ of $\alpha$-D-fructose with the presence of a vestigial quantity of D-glucopyranose isomers. We used anhydrous conditions to avoid amide hydrolysis. The isomerization of compounds 2a-f also showed an 8:2 mixture of the $\beta / \alpha$ anomers by ${ }^{1} \mathrm{H}$ NMR spectroscopy.

All our compounds were evaluated for their antiproliferative activity against two cell lines, human breast adenocarcinoma (MCF-7) and human colon adenocarcinoma (MDST8). Batches of cells were cultured for $72 \mathrm{~h}$ with the compounds in the concentration range of $1 \times 10^{-9}-1 \times 10^{-5} \mathrm{M}$. Cell proliferation was determined using Cell Counting Kit (Sigma). 5-FU was used as positive control for both cell lines. Whenever possible the $\mathrm{IC}_{50}$ values, corresponding to a $50 \%$ inhibition of proliferation, were determined by fitting the results to a dose-response growth sigmoidal curve using Origin Software (OriginLab Corporation). The antiproliferative results are representative of $n=2-3$ independent experiments with 5 replicates each. 5 -FU showed $\mathrm{IC}_{50}$ values of $6.4 \times 10^{-8} \mathrm{M}$ and $5.2 \times 10^{-7} \mathrm{M}$ for MDST8 and MCF-7, respectively (data not shown). At the highest concentration used, $1 \times 10^{-5} \mathrm{M}, 5-\mathrm{FU}$ inhibited colon and breast cell growth by 83 and $60 \%$, respectively (Fig. 3).

Antiproliferative activity at a concentration of $1 \times 10^{-8} \mathrm{M}(50 \%$ of inhibition) in the MDST8 cell line was only observed in the case of 4 a containing a $\mathrm{Br}$, this compound had more than $90 \%$ of an antiproliferative effect at $1 \times 10^{-5} \mathrm{M}$, and was more active than 5-FU Hydroxy-D-fructuronamide derivative $3 \mathbf{c}$ with an isopropyl substituent, had $80 \%$ of an antiproliferative effect at $1 \times 10^{-5} \mathrm{M}$ against MDST8 cell line, and was more active than its isomer $\mathbf{2 c}$. Compound 3d had an antiproliferative effect in the MCF-7 cell line and showed similar inhibition as 5-FU. In the case of those compounds with aromatic substituents, like 2a and 3a (benzyl) and 2b and $\mathbf{3 b}$ (phenyl), they didn't show any antiproliferative activity in the MDST8 and MCF-7 cell lines. $\mathbf{2 e - f}$ and $\mathbf{3 e - f}$, were shown to 

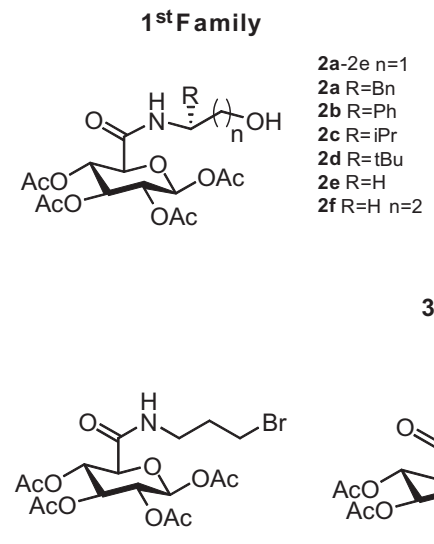

$4 a$
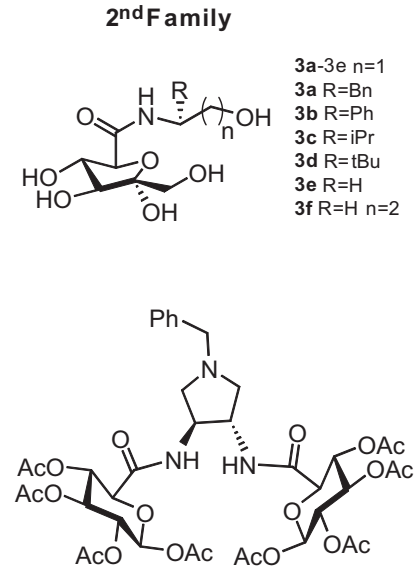

$4 c$

Figure 2. Libraries of novel hydroxyamide and amides derivatives derived from D-glucuronic acid.
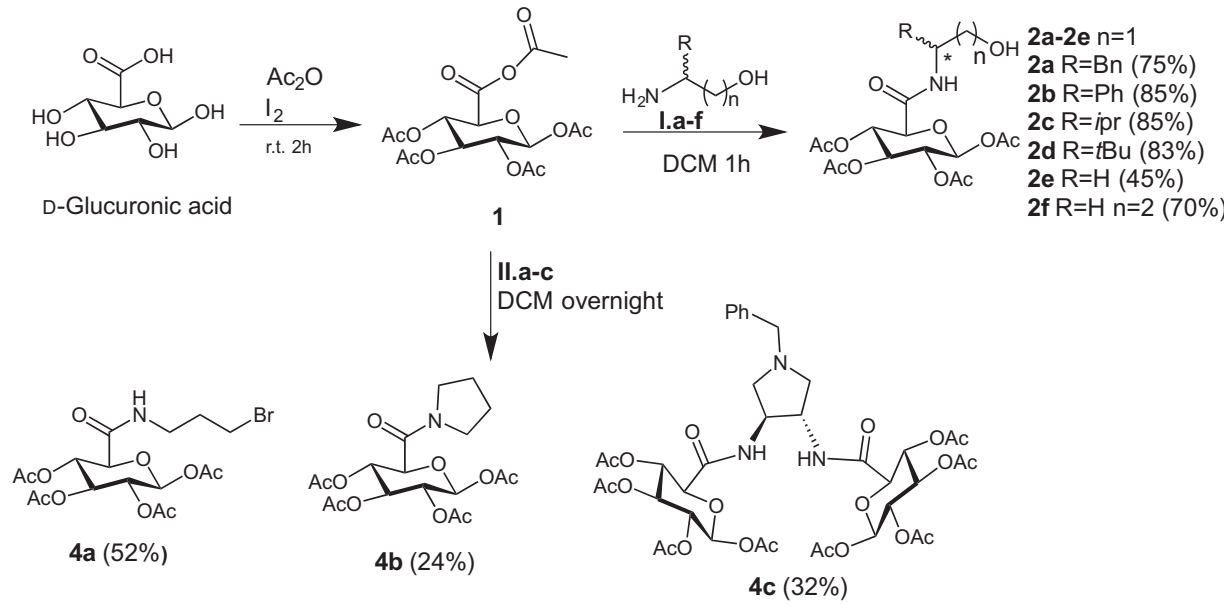

Scheme 1. Synthesis of acetylated hydroxy- $\beta$-D-glucopyranuronamide $\mathbf{2 a - 2 f}$ ( 1 st family) and $\beta$-D-glucopyranuronamide $\mathbf{4 a - 4 c}$ ( 3 rd family).
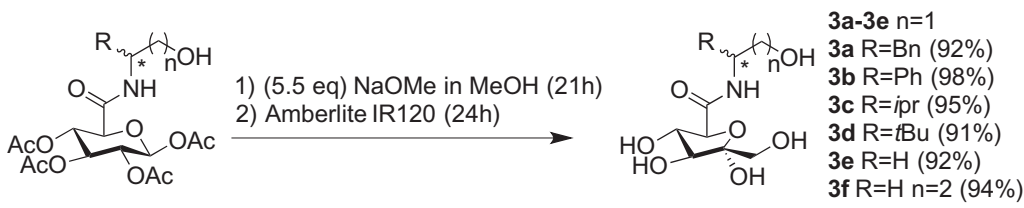

Scheme 2. Isomerization of hydroxy- $\beta$-D-glucopyranuronamides (2a-2f) to hydroxy- $\beta$-D-fructuronamides (3a-3f).

be the most promising compounds in the case of the MCF-7 cell line, these four compounds inhibited the cell proliferation by more than $60 \%$, and were also more effective than 5 -FU. $3 f$ exhibited more antiproliferative activity at $1 \times 10^{-5} \mathrm{M}$ concentration. These compounds were inactive against the MDST8 cell line. The hydroxy-D-fructuronamides (2nd Family), showed similar antiproliferative effects as their respective acetylated isomers. This could be explained on the basis of a rather narrow dynamic range for these compounds that is probably related with their mechanism of action. Compounds $2 \mathbf{e}$ and $\mathbf{2} \mathbf{f}$ are expected to dissolve in the lipid bilayer, and are likely to disturb membrane function. The lipid environment in each cell line may influence the degree of accumulation of the inhibitors in the plasma membrane, hence the differential effects observed. Compounds $\mathbf{3 d}, \mathbf{3 e}$ and $\mathbf{3 f}$ contain a fructose-like ring that is too polar to permeate the lipid bilayer but because of this structural motif are potential inhibitors of the GLUT5 receptor which is overexpressed by MCF- $7^{12}$ but not as much by the MDST- 8 cell line. To assess the dose-dependent effect, tests using a different range of concentrations would be necessary.

In the case of the 3rd Family, the amide derivatives containing a pyrrolidine unit, that is, $\mathbf{4 b}$ and $\mathbf{4 c}$, compound $\mathbf{4 b}$ was shown to be active in the both cell lines, but more active in the MCF-7 cell line with an $\mathrm{IC}_{50}$ of $1 \times 10^{-6} \mathrm{M}$. Bis-amide compound $4 \mathrm{c}$ was only active in the MDST8 cell line with an $\mathrm{IC}_{50}$ of $1 \times 10^{-7} \mathrm{M}$.

It is likely that the acetylated compounds used in this study suffer cleavage of their labile ester group inside the cell due to the action of esterases or other hydrolytic agents, making them more bio-active entities, probably via stronger interactions with the HDACs through H-bonding. Compounds (4a-4c) inhibited proliferation of both cell lines but were more effective for MDST8. 


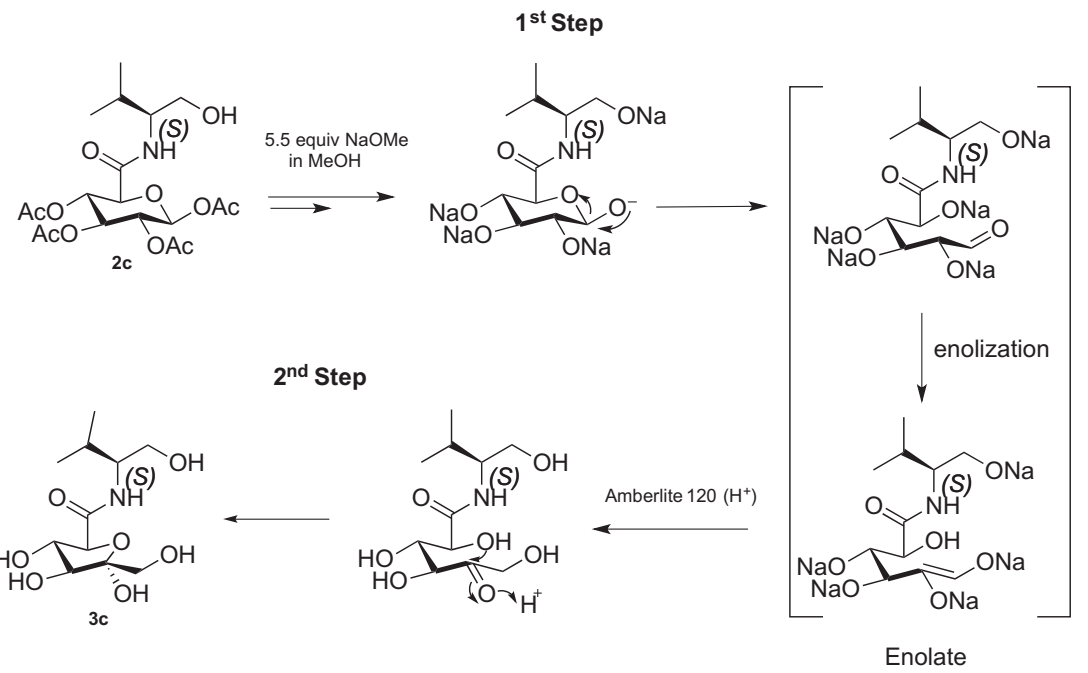

Scheme 3. Proposed mechanism for isomerization of the hydroxy- $\beta$-D-glucopyranorunamide $2 \mathbf{c}$ to $\mathbf{3 c}$.
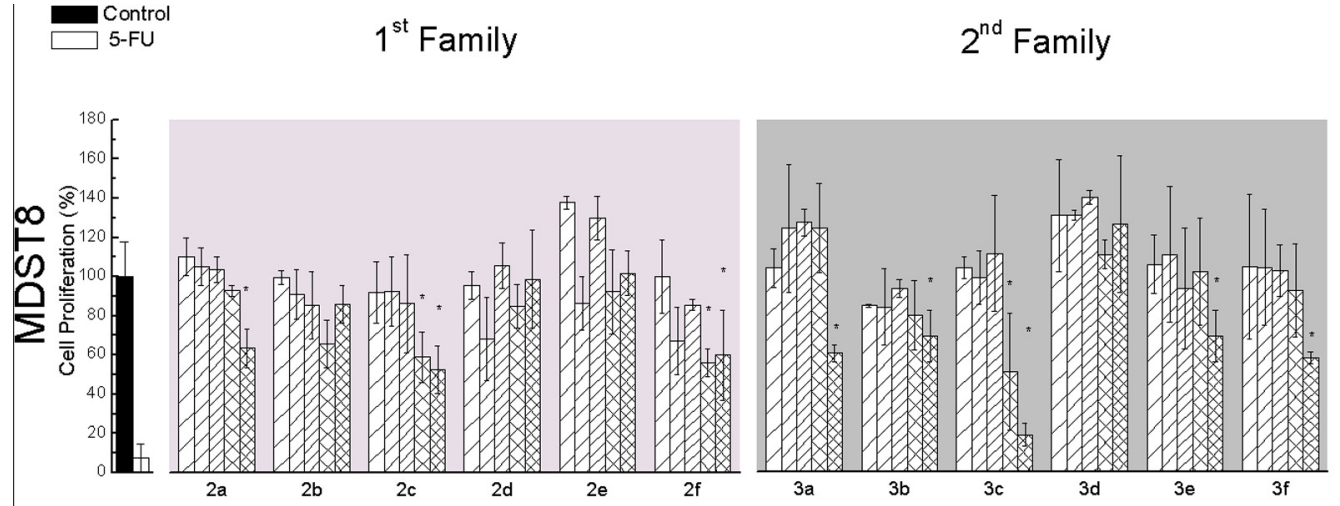

$2^{\text {nd }}$ Family

$3^{\text {rd }}$ Family
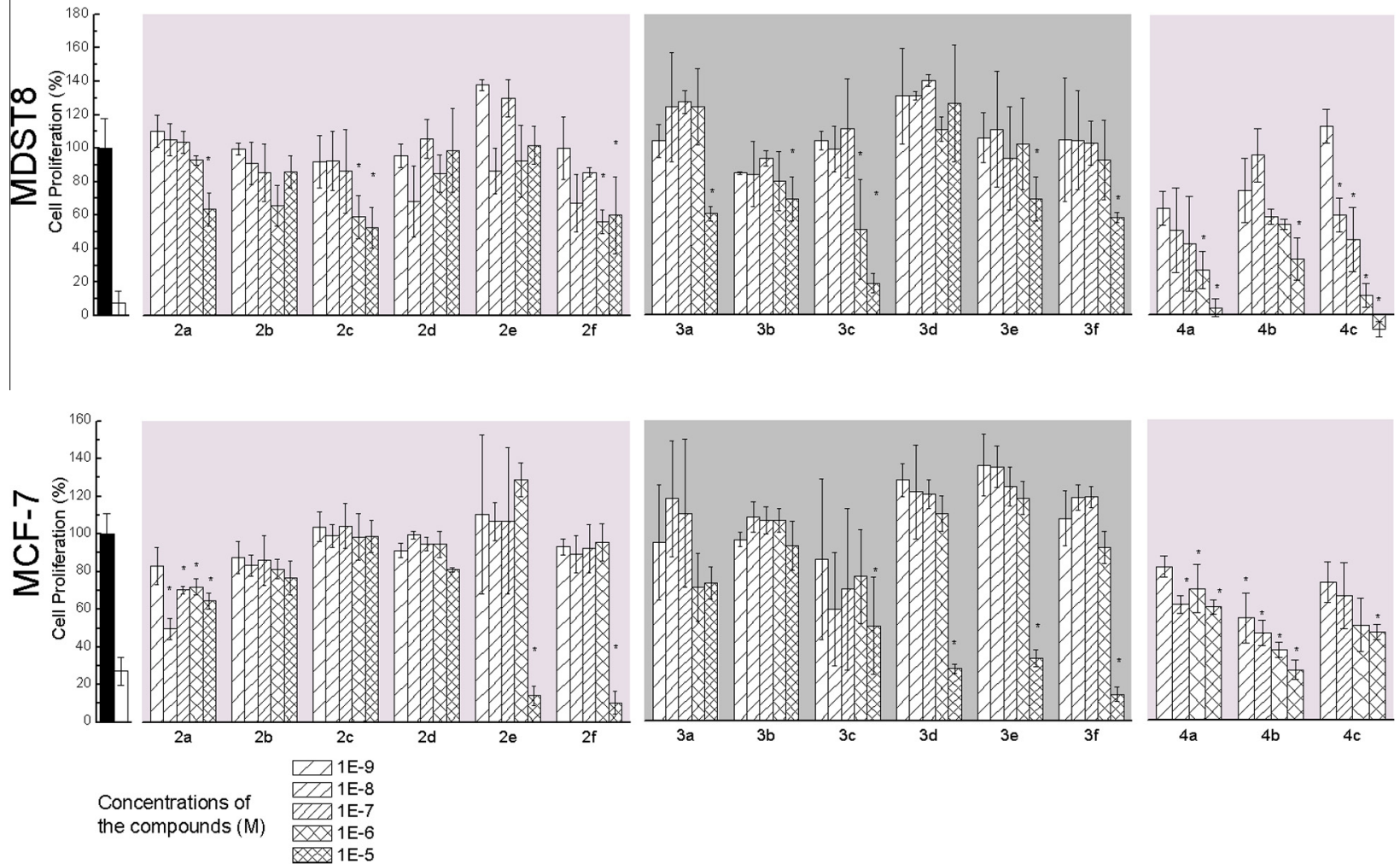

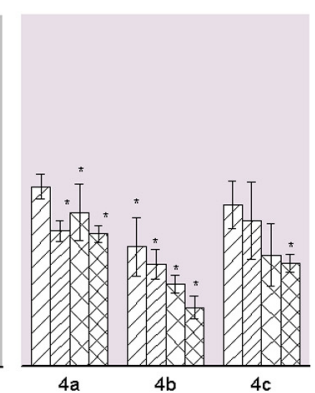

$4 c$

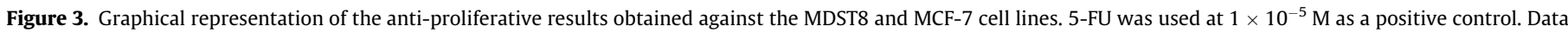
are presented as means \pm SD ( ${ }^{*}$ significant for $\left.P<0.05\right)$.

The $\mathrm{IC}_{50}$ values were obtained at concentrations between 0.01 and $10 \mu \mathrm{M}$, similar to those for the medicinal compounds $\mathbf{A}$ and B shown in Fig. 1.

A structure-activity relationship (SAR) was observed for fifteen of our compounds. For the hydroxyamides containing benzyl and phenyl units (1st and 2nd families; 2a, 2b, 3a and 3b) low activity in both cell lines was observed, and there was no significant enhancement in activity on changing the structure of the sugar from glucose to fructose. The antiproliferative activity in both cell-lines was enhanced on changing the aromatic unit for an alkyl substituent (3c and 3d) in this group. Compound $\mathbf{3 c}$ containing an isopropyl unit showed an antiproliferative effect only against the MDST8 cell line and the tert-butyl containing analogue 3d was selective for only the MCF-7 cell line. The hydroxy- $\beta$-D-glucopyranuronamides $\mathbf{2 e - 2 f}$ and the hydroxy- $\beta$-D-fructuronamides $\mathbf{3 e}$ and 3f containing a non-substituted linear amide side-chain, were 
active and selective for only the MCF-7 cell line. On the contrary, compound 4a, containing a bromo-substituted linear amide sidechain, was active for the MDST8 cell line but inactive in the MCF7 cell line. Indicating that the $\mathrm{OH}$ group is important in MCF-7 antiproliferative activity. The effect of the $\mathrm{OH}$ in the amide sidechain on the activity of the molecule was enhanced by increasing the side-chain length (compare those analogues containing ethyl (2e and 3e) and propyl ( $\mathbf{2 f}$ and $\mathbf{3 f}$ ) chains in the amide unit). Compound $\mathbf{4 b}$ containing a pyrrolidinyl substituent was shown to be the most active inhibitor against MCF-7.

In conclusion, we synthesized three new families of hydroxyamides and amides derived from D-glucuronic acid, using simple but efficient synthetic methods. Their antiproliferative activity against two cancer cell lines, MDST8 and MCF-7, were studied and some showed good antiproliferative activity. Compounds $\mathbf{2 e}$, 2f, 3d, 3e, 3f and $\mathbf{4 b}$ were shown to be active against MCF-7, with an anti-proliferative effect in the $1 \mu \mathrm{M}$ to $10 \mu \mathrm{M}$ concentration range. Compounds $\mathbf{3 c}, \mathbf{4 a}, \mathbf{4 b}$ and $\mathbf{4 c}$ were shown to be active against MDST8. The amide derivatives exhibited a stronger antiproliferative effect than the hydroxyamides, in both families (against MDST8). Compound 4a was selective for MDST8 and the best inhibitor having an $\mathrm{IC}_{50}$ of $100 \mathrm{nM}$. Compound $4 \mathrm{a}$ containing a 3-bromopropyl amide side-chain gave the best results for this cell line. In the case of the MCF-7 cell-line, hydroxyamide compounds (2e, 2f, 3d, 3e, 3f) were generally more active than the amide derivatives $(\mathbf{4 a}-\mathbf{4} \mathbf{c})$, however the lowest $\mathrm{IC}_{50}$ was obtained for $\mathbf{4 b}(1 \mu \mathrm{M})$. On comparing the activity of our compounds with 5-FU, some showed better biological activity than 5-FU. 4a and 4c presented better activity than this bench-mark compound against the MDST8 cell line. With regard to the MCF-7 cell line, compounds $2 \mathbf{e}, \mathbf{2 f}, \mathbf{3 f}$ showed better activity than 5-FU. These families of $\beta$-D-glucopyranose and $\beta$-D-fructose derivatives appear to be promising candidates for inhibiting both MDST8 and MCF-7 cell lines. Further studies are continuing at developing more potent analogues for these cell-lines and at probing their molecular target.

\section{Acknowledgments}

EPC thanks the Fundação para a Ciência e a Tecnologia (FCT) for a post-doctoral research fellowship (SFRH/BPD/72182/2010). We are extremely grateful to Dr. Olivia Furtado Burke of LNEG, Lisbon for the optical activity measurements. We are grateful also from funding from FCT via the Strategic Projects PEst-OE/QUI/ UI0619/2014. PEst-C/SAU/LA0001/2011 (CNC), PEst-OE/SAU/ UI4013/2014 and PEst-C/QUI/UI0062/2011 (ICAAM). We are grateful to Dr. Albertino Goth for all the NMR experiments and to project LADECA (ALENT-07-0262-FEDER-001878) for financing the acquisition of the Bruker Avance III NMR spectrometer.

\section{Supplementary data}

Supplementary data associated with this article can be found, in the online version, at http://dx.doi.org/10.1016/j.bmcl.2015.12. 036.

\section{References and notes}

1. (a) Tiwari, V. K.; Mishra, R. C.; Sharma, A.; Tripathi, R. P. Mini Rev. Med. Chem. 2012, 12, 1497; (b) Klyosov, A. A. In Glycobiology and Drug Design; Klyosov, A. A., Ed.; Amer. Chem. Soc., 2012; pp 3-22. ch1.

2. (a) Fox, J. J.: Kuwada, Y: Watanabe, K. A. Tetrahedron Lett. 1968, 9, 6029; (b) Take, N. Ō.; Akeuchi, S.; Endō, T.; Yonehara, H. Tetrahedron Lett. 1965, 6, 1411; (c) Timoshchuk, V. A. Pharm. Chem. J. 1995, 29, 51.

3. (a) Juan, T.-Y.; Roffler, S. R.; Hou, H.-S.; Huang, S. M.; Chen, K. C.; Leu, Y. L.; Prijovich, Z. M.; Yu, C. P.; Wu, C. C.; Sun, G. H.; Cha, T. L. Clin. Cancer Res. 2009, 15, 4600; (b) Tranoy-Opalinski, I. Eur. J. Med. Chem. 2014, 74, 302.

4. (a) El-Nezhawy, A. O. H.; Gaballah, S. T.; Radwan, M. A. A.; Baiuomy, A. R.; Adbel-Salam, O. M. E. Med. Chem. 2009, 5, 558; (b) El-Nezhawy, A. O. H.; Adly, F. G.; Eweas, A. F.; Hanna, A. G.; El-Kholy, Y. M.; El-Sayed, S. H.; El-Naggar, T. B. A. Arch. Pharm. Chem. Life Sci. 2011, 344, 648.

5. Jain, D. K.; Singh, A.; Patel, V. K.; Sharma, P. C.; Gupta, A. K.; Sharma, A. K.; Rajak, H. Int. J. Pharm. Pharm. Sci. 2014, 6, 648. and citation there in.

6. Rosato, R. R.; Grant, S. Expert Opin. Investig. Drugs 2004, 13, 21

7. Butler, L. M.; Zhou, X.; Xu, W.-S.; Scher, H. I.; Rifkind, R. A.; Marks, P. A.; Richon, V. M. PANS 2002, 99, 11700.

8. Finnin, M. S.; Donigian, J. R.; Cohen, A.; Richon, V. M.; Rifkind, R. A.; Marks, P. A.; Breslow, R.; Pavletich, N. P. Nature 1999, 401, 188

9. Guerrant, W.; Patil, V.; Canzoneri, J. C.; Oyelere, A. K. J. Med. Chem. 2012, 55, 1465.

10. Tatibouët, A.; Yang, J.; Morin, C.; Holman, G. D. Bioorg. Med. Chem. 1825, 2000, 8.

11. (a) Trayner, B. J.; Grant, T. N.: West, F. G.; Cheeseman, C. I. Bioorg. Med. Chem. 2009, 17, 5488; (b) Levi, J.; Cheng, Z.; Gheysens, O.; Patel, M.; Chan, C. T.; Wang, Y.; Namavari, M.; Gambhir, S. S. Bioconjugate Chem. 2007, 18, 628.

12. (a) Zamora-León, S. P.; Golde, D. W.; Concha, I. I.; Rivas, C. I.; Delgado-López, F ; Baselga, J.: Nualart, F.; Vera, J. C. Proc. Natl. Acad. Sci. U.S.A. 1847, 1996, 93; (b) Chan, K. K.; Chan, J. Y. W.; Chung, K. K. W.; Fung, K.-P. J. Cell. Biochem. 2004, 93, 1134; (c) Godoy, A.; Ulloa, V.; Rodrı́́uez, F.; Reinicke, K.; Yañez, A. J.; Garci, M. D.: Medina, R. A.; Carrasco, M.; Barberis, S.; Castro, T.; Martı́n ez, F.; Koch, X. Vera, J. C.; Poblete, M. T.; Figueroa, C. D.; Peruzzo, B.; Perez, F.; Nualart, F. J. Cell. Physiol. 2006, 207, 614

13. (a) Lo, K. K.-W.; Law, W. H.-T.; Chan, J. C.-Y.; Liu, H.-W.; Zhang, K. Y. Metallomics 2013, 5, 808; (b) Zhang, K. Y.; Tso, K. K.-S.; Louie, M.-W.; Liu, H.-W.; Lo, K. K.-W. Organometallics 2013, 32, 5098.

14. Souza, R. O. L.; Fabiano, D. P.; Feche, C.; Rataboul, F.; Cardoso, D.; Essayem, N. Catal. Today 2012, 195, 114

15. Román-Leshkov, Y.; Moliner, M.; Labinger, J. A.; Davis, M. E. Angew. Chem., Int. Ed. 2010, 49, 8954.

16. Saravanamurugan, S.; Paniagua, M.; Melero, J. A.; Riisager, A. J. Am. Chem. Soc. 2013, 135, 5246.

17. Cho, J. K.; Kim, S. Y.; Cho, J. H.; Kim, B. R.; Joo, J. US 2014/0235881A1, 2014.

18. Fiaux, H.; Kuntz, D. A.; Hoffman, D.; Janzer, R. C.; Gerber-Lemaire, S.; Rose, D. R.; Juillerat-Jeanneret, L. Bioorg. Med. Chem. 2008, 16, 7337. and citation there in.

19. Nomura, N.; Verdon, G.; Kang, H. J.; Shimamura, T.; Nomura, Y.; Sonoda, Y.; Hussien, S. A.; Qureshi, A. A.; Coincon, M.; Sato, Y.; Abe, H.; Nakada-Nakura, Y.; Hino, T: Arakawa, T.; Kusano-Arai, O.; Iwanari, H.; Murata, T.; Kobayashi, T.; Hamakubo, T.; Kasahara, M.; Iwata, S.; Drew, D. Nature 2015, 526, 397.

20. Tosin, M.; Murphy, P. V. Org. Lett. 2002, 4, 3675. 